\title{
METHODOLOGY OF JOINT PHYSICAL EDUCATION AND RECREATION CLASSES UNDER THE PROGRAM "MOM + BABY"
}

\author{
METODOLOGIA DAS AULAS CONJUNTAS DE EDUCAÇÃO FÍSICA E RECREAÇÃO \\ DO PROGRAMA "MAMÃE + BEB $\hat{E}^{\prime \prime}$
}

\author{
METODOLOGÍA DE LAS CLASES CONJUNTAS DE EDUCACIÓN FÍSICA Y \\ RECREACIÓN DEL PROGRAMA "MOM + BABY"
}

\author{
Sergey Alekseevich YARUSHIN ${ }^{1}$ \\ Valentin Dmitrievich IVANOV ${ }^{2}$ \\ Tatyana Nikolaevna VLASENKO ${ }^{3}$ \\ Viktor Ivanovich GONCHAROV ${ }^{4}$ \\ Tatyana Anatolevna BANKU ${ }^{5}$ \\ Evgeniya Aleksandrovna GERASIMCHUK ${ }^{6}$ \\ Olga Sergeevna KRUTSKIH ${ }^{7}$ \\ Tatyana Valerievna PINCHUK ${ }^{8}$
}

ABSTRACT: The relevance of this work can be considered in two aspects: from the point of view of physical education of early children and physical education of women on leave to care for a child under 3 years. The article presents the results of the study on the organization of fitness classes under the program "Mom + Baby." The purpose of the article is to provide a scientific justification for the effectiveness of conducting joint physical education and recreation classes under the program "Mom + Baby." The main methods of the study were analysis and synthesis of information sources, survey, observation, testing, and the method of

${ }^{1}$ Chelyabinsk State University (CSU), Chelyabinsk - Russia. Associate Professor, Head of the Department of Physical Education and Sports. PhD Candidate of Pedagogical Sciences. ORCID: https://orcid.org/0000-00015213-5298. E-mail: yarushinsa@gmail.com

${ }^{2}$ Chelyabinsk State University (CSU), Chelyabinsk - Russia. Associate Professor, Department of Physical Education and Sports. PhD Candidate of Pedagogical Sciences. ORCID: https://orcid.org/0000-0002-2952-3222. E-mail: vdy-55@mail.ru

${ }^{3}$ Branch of the Far Eastern Federal University in Ussuriysk (FEFU), Ussuriysk - Russia. Associate Professor, Department of Theory, Methodology and Practice of Physical Culture and Sports. PhD Candidate of Pedagogical Sciences. ORCID: https://orcid.org/0000-0002-4960-0416. E-mail: vlasenko15@mail.ru

${ }^{4}$ Branch of the Far Eastern Federal University in Ussuriysk (FEFU), Ussuriysk - Russia. Associate Professor, Head of the Department of Theory, Methodology and Practice of Physical Culture and Sports. PhD Doctor of Psychological Sciences. ORCID: https://orcid.org/0000-0001-7166-6983. E-mail: victorgoncharov@yandex.ru

${ }^{5}$ Branch of the Far Eastern Federal University in Ussuriysk (FEFU), Ussuriysk - Russia. Associate Professor, Department of Theory, Methodology and Practice of Physical Culture and Sports. PhD Candidate of Pedagogical Sciences. ORCID: https://orcid.org/0000-0002-6054-6190.E-mail: tovachik@mail.ru

${ }^{6}$ Primorsky State Agricultural Academy (RUSVUZ), Ussuriysk - Russia. Teacher of Physical Culture and Sports, Department of Natural Science and Socio-economic Disciplines. ORCID: https://orcid.org/0000-0002-3030-4617. E-mail: familly1708@gmail.com

7 Branch of the Far Eastern Federal University in Ussuriysk (FEFU), Ussuriysk - Russia. Senior Lecturer, Department of Theory, Methodology and Practice of Physical Culture and Sports. ORCID: https://orcid.org/00000003-3268-0429. E-mail: olga 24luck@mail.ru

8 Primorsky State Agricultural Academy (RUSVUZ), Ussuriysk - Russia. Senior Lecturer, Inter-Institute Department of Natural Science and Socio-Economic Disciplines. ORCID: https://orcid.org/0000-0001-8740-4013. E-mail: ptv.fk.pgsha@mail.ru 
Sergey Alekseevich YARUSHIN; Valentin Dmitrievich IVANOV; Tatyana Nikolaevna VLASENKO; Viktor Ivanovich GONCHAROV; Tatyana Anatolevna BANKU; Evgeniya Aleksandrovna GERASIMCHUK; Olga Sergeevna KRUTSKIH and Tatyana Valerievna PINCHUK

expert assessment. The effectiveness of the impact of the developed methodology on increasing the competence of women in the physical development of young children and the formation of their motor skills was piloted.

KEYWORDS: Program "Mom+Baby". Women 20-35 years old. Young children. Motor skills. Social adaptation. Education.

RESUMO: A relevância deste trabalho pode ser considerada em dois aspectos: do ponto de vista da educação física da primeira infância e da educação física da mulher afastada para cuidar de um filho menor de 3 anos. $O$ artigo apresenta os resultados do estudo sobre a organização de aulas de fitness no âmbito do programa "Mamãe + Bebê". O objetivo do artigo é fornecer uma justificativa científica para a eficácia da realização de aulas conjuntas de educação física e recreação no âmbito do programa "Mamãe + Bebê". Os principais métodos do estudo foram a análise e síntese das fontes de informação, levantamento, observação, teste e o método de avaliação por especialistas. Foi testada a eficácia do impacto da metodologia desenvolvida no aumento da competência das mulheres no desenvolvimento fisico de crianças pequenas e na formação de suas habilidades motoras.

PALAVRAS-CHAVE: Programa "Mamãe + Bebê". Mulheres de 20 a 35 anos. Crianças pequenas. Habilidades motoras. Adaptação social. Educação.

RESUMEN: La relevancia de este trabajo se puede considerar en dos aspectos: desde el punto de vista de la educación física de la primera infancia y la educación física de las mujeres en excedencia para el cuidado de un hijo menor de 3 años. El artículo presenta los resultados del estudio sobre la organización de clases de fitness bajo el programa "Mamá + Bebé". El propósito del artículo es proporcionar una justificación cientifica de la efectividad de realizar clases conjuntas de educación física y recreación bajo el programa "Mamá + Bebé". Los principales métodos del estudio fueron el análisis y síntesis de fuentes de información, la encuesta, la observación, las pruebas y el método de evaluación de expertos. Se puso a prueba la eficacia del impacto de la metodología desarrollada en el aumento de la competencia de las mujeres en el desarrollo físico de los niños pequeños y la formación de sus habilidades motoras. El artículo también presenta evidencia de la dinámica positiva de la aptitud física de las mamás y las habilidades motoras de los niños involucrados con ellas.

PALABRAS CLAVE: Programa "Mamá + Bebé". Mujeres de 20 a 35 años. Niños pequenos. Habilidades motoras. Adaptación social. Educación.

\section{Introduction}

The problems of education and development of pre-school age children in the scientific and methodological literature are well presented. The analysis of information sources showed that about $60 \%$ of the works are devoted to children aged 4 to 7 years; $30 \%$ - cover the issues of children under one year, and only $10 \%$ - focus on children of the early age (from 1 to 3 years) (KROKHINA; APARIEVA, 2015). Topics of these 10 percent of scientific and methodological 
works can be divided into the following issues: health improvement and preventive health-care (massage and preventive treatment), development of fine motor skills and intelligence (development of creative abilities, early language training) (OBNOSOV; ASOMBA, 2020; FEDOROVA, 2014).

The social value of the problem under study is in the fact that at present there is no impact of state on the process of raising children from 1 to 3 years old, which is supposed to be be done by parents. It is mothers who officially go on parental leave to care of children under the age of three, so most of the educational functions are assigned to them. The choice of additional training for young children is on their parents: in private kindergartens (nursery group), in private educational clubs. And in sports classes, studios of various kinds of dance accept children from the age of three.

The period of early childhood (from one to three years) it is one of the most important and critical stages of a child's development (BUZYKOVA, 2017; GOLUBEVA, 2014; GORCHAKOVA; TSIVILEVA, 2019; MARTYNOV, 2017). As A.I. Kravchuk notes: "[...] the age-related features of the development of children's motor abilities, the differences in the PE and learning of children of each year of life are not sufficiently studied. The issues of consistency and quality of motor skills development are poorly covered" (KRAVCHUK, 2007). Previously, we have already pointed out that "the problems of physical education of children from one to three years old are not sufficiently studied, and there is practically no method of teaching mothers of developing training with their babies" (VLASENKO; POPESCU, 2019).

It should be noted that up to 3 years of age, children develop basic motor skills of walking, running, jumping over and down, catching and throwing, creeping and climbing, and others (ISLAMOVA, 2019; SMALL, 2015; SMIRNOVA; GALIGUZOVA; MESHCHERYAKOVA, 2018; TEREKHINA; MEDVEDEV; SUPRUN, 2019).

If we consider the problem in a different perspective (of women who are on leave to care for a child up to 3 years old), then the relevance of this work will be no less problematic. During maternity leave, many women try to find an opportunity to take care of themselves: their appearance, their fitness. The situation is aggravated in cases when a woman has given birth to a second or third child and is forced to devote herself to housework and child care. In this regard, the joint sports and recreation classes program "Mom+Baby" is one of the alternative ways to solve the issues of recovery after childbirth, switching women's attention to their health, gaining knowledge in the field of sports and recreation activities, as well as knowledge in the field of physical education of children under 3 years of age and problems related to their motor activity and early socialization. 


\section{The purpose of the study}

To scientifically substantiate the effectiveness of the methodology of joint physical culture and recreation training program "Mother+Baby".

\section{In accordance with the goal, the research tasks are defined at the research level}

- elaborate a gradation of the levels of parents competence in matters of physical education and early childhood development;

- test the competence of parents with young children (from 1 year to three years) in the field of physical education and development of their children;

- to evaluate the results of the impact of the developed methodology on the physical fitness of women;

- to evaluate the result of the experimental technique impact on the formation of motor skills in children.

\section{Methods and organization of the study}

To solve the tasks, the following methods were used: theoretical (analysis of scientific sources and methodological literature); empirical (survey-testing, observation, pedagogical testing, pedagogical experiment, expert evaluation method); statistical (mathematical processing of the results obtained during the study). The study involved women with young children (from 1 year to three years).

To assess the competence of parents in matters of physical education and development of young children (from 1 year to three years) a test questionnaire consisting of 21 questions was formed with the use of Google Classroom. Each test question contained a correct answer, for which 1 point was given, and an incorrect one was scored with 0 points. As a result, the respondent could score 21 points. Further we elaborated a gradation of the levels of parents competence in matters of physical education and early childhood development:

- high level - from 21 to 18 points (100-86 \% correct answers);

- average level - from 17 to 15 points (85-71\% of correct answers);

- below the average level - from 14 to 12 points (70-56 \% of correct answers);

- low level - 11 points or less (55\% or less correct answers). 
143 women aged 20-35 from different regions of Russia with young children took part in the survey-testing. We posted a link to the test on social networks in groups of moms (in Whatsapp and Instagram).

For conducting pedagogical testing of women, we have selected the most informative tests characterizing physical fitness:

- arms bending and stretching in a kneeling position - knee push-ups (test on strength of arms and shoulder girdle),

- lifting and lowering back down the torso lying on the back, hands behind the head (power endurance),

- test of standing in the "forearm plank" position (static strength endurance of the muscles of the arms, shoulder girdle, body's natural corset),

- test "stand on one leg with eyes closed" (coordination ability, ability to maintain balance),

- flexibility test of torso tilt from a standing position (active flexibility of the spine).

Testing of endurance and speed skills on the stadium was not carried out, because the women had young children.

The expert assessment method was used to identify the results of the educational impact of the experimental technique on the formation of motor skills in young children. The expert commission consisted of three people: a trainer-instructor of the group "Fitness-baby", Candidate of pedagogical sciences, associate professor of the Department of Theory, Methodology and Practice of Physical Culture and Sports of the Far Eastern Federal University filial in Ussuriysk, and an instructor in physical culture of the preschool educational institution "Kindergarten No. 39".

To assess the level of basic motor skills development in children, we selected the methodology described in the dissertation of Menyailova (2009), modified it with accordance of the material and technical support of the experimental site and adapted it to the age characteristics of early childhood children. Each skill could score from zero to five points. 5 skills were evaluated: walking, running, balance skills (on a restricted space), throwing skills, skills of throwing and catching the ball, crawling through a children's folding tunnel (2 meters long).

The experimental base of the study was the sports and recreation center in Ussuriysk. The study involved 20 women aged 20 to 35 years with young children. 10 couples - 
Mother+Baby were engaged in the training based on the author's methodology which aimed at addressing the needs of women in self-improvement and organizing physical education of young children. Another 10 couples made up a control group: women were engaged in fitness clubs in the city separately from their kids, and they had to perform tasks with the kids at home accordingly to our recommendations. After evaluating and analyzing the performance of women's physical fitness, their competence in the issues of physical education of young children and the level of motor skills development in children before the experiment, we noted the homogeneity of the groups $(\mathrm{P}>0.05)$.

Experimental technique. The content of the methodology included the purpose and objectives of each class. In general, a differentiated approach was used in the course of classes, with the general provisions of physical education and wellness training taken into account. The funds were deployed with the consideration of training impact on the body of the women and children. Special attention was paid to multi-purpose exercises. Their planning was carried out on the basis of the tasks set, the individual characteristics of physical development, and the physical fitness of women. The methodology also provided for the zoning of the gym.

The objectives of the classes: organization of physical culture and health training among women who are on parental leave; organization of physical education of young children through classes with mothers.

\section{Training objectives:}

1. Recovery of women after childbirth: improving the physical fitness of women, gradually increasing their functional capabilities, improving their psychological state.

2. Teaching children basic motor skills through play tasks performed with their mother.

3. Socialization of young children.

Classes were held twice a week in the morning from 10 to 11 o'clock - the time when the child is usually awake and ready to learn.

We paid special attention to the zoning of the gym (Fig. 1, 2). 
Figure 1 - An educational zone for children

Source: Collection of the authors

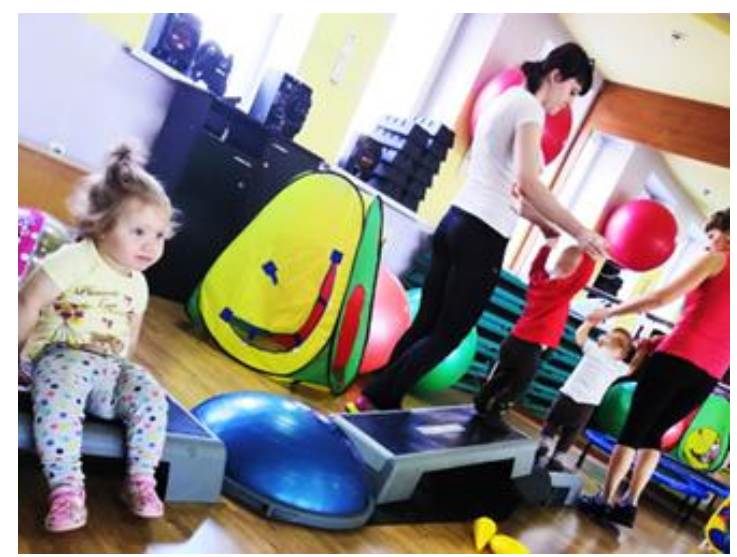

Figure 2 - Central zone for training

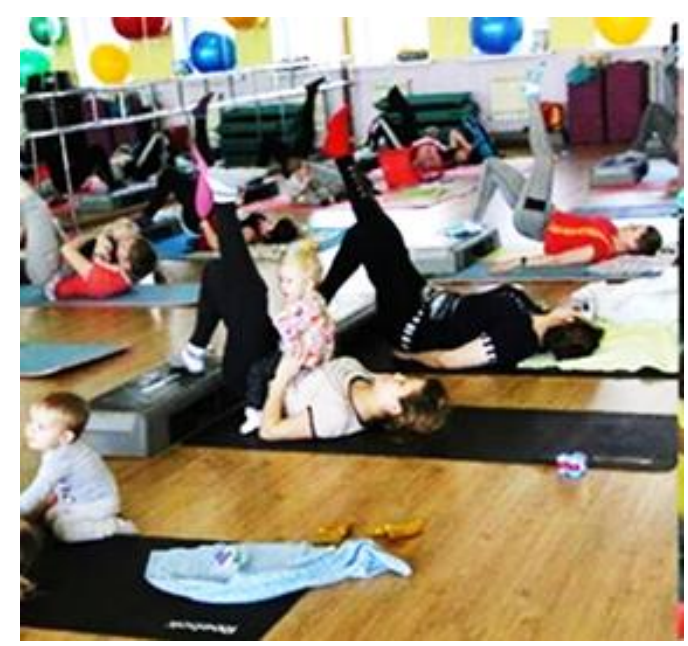

Source: Collection of the authors

In the center, gymnastic mats are laid out for the mothers (if necessary, we put a second one for the child). On the one hand, we separate the play zone, where we have a folding pool with toys, a children's mini trampoline, folding houses with toys. On the other side of the hall, we are preparing a training zone for mobile children. We arrange a track of step platforms, lay out children's tunnels, add a track of gym mats.

The class is based on the type of fitness training. Each class is divided into three parts: preparatory, main and final (Fig. 3). 
Figure 3 - Diagram of the structure of the class

\begin{tabular}{|c|c|}
\hline \multicolumn{2}{|c|}{ Preparatory part (15-17 minutes) } \\
\hline $\begin{array}{c}\text { Warm-up } \\
(10-12 \text { minutes })\end{array}$ & $\begin{array}{l}\text { Adaptation of the child in the gym and } \\
\text { group (5-7 minutes) }\end{array}$ \\
\hline \multicolumn{2}{|c|}{ The main part ( $35-40$ minutes) } \\
\hline $\begin{array}{c}\text { Exercises for women ( } 20-25 \text { minutes) } \\
\text { - aerobic exercise for moms; } \\
\text { - power training for moms. }\end{array}$ & $\begin{array}{l}\text { Exercises for children with mothers } \\
\qquad(10-15 \text { minutes })\end{array}$ \\
\hline \multicolumn{2}{|c|}{ The fin al part (5-10 minutes) } \\
\hline $\begin{array}{l}\text { Stretching exercises } \\
\text { - Fitball exercises } \\
\text { - Breathing exercises }\end{array}$ & Relaxation exercises \\
\hline
\end{tabular}

Source: Collection of the authors

\section{The preparatory part of the lesson consists of two parts:}

-5-7 minutes are allocated for the adaptation of the child to the situation in the gym and the group. Mothers, coming to the gym, greet everyone, choose a comfortable place, prepare a mat, equipment, go with the baby to the play zone, so that the child and his mother can adapt to the new environment and new people. If the child does not stay there with other children, the one takes the toys one likes and goes with his mother to his place, sits down and plays next to his mother;

- 10-12 minutes of a warm-up for mothers using the simplest exercises of basic aerobics. Special attention is paid to stretching of the back, ligaments and leg muscles, warming up the muscles, gradually increasing the heart rate to the aimed level of physical activity in the main part of the training. Children at this time play by themselves on the playground or educational platform. If the child is naughty, the mother sets the child next to her on the mat or takes it in her arms, calms the child and only then continues the class. Gradually, the child gets used to the set mode of the situation and stops being naughty and enjoys playing with other children or independently. Mothers intervene only if the children do not share the toys or the child is in danger (may fall or hit another child). 
The main part of the lesson is divided into two parts: exercises for mothers (20-25 minutes) and exercises for children with mothers (10-15 minutes). First, aerobic exercises are performed. Various means of modern fitness programms are used: Step Aerobics, Dance Fitness, Bosu, Tabata, Crossfit, etc. The mother uses the child as a weighting device for no more than 3 minutes (at the request of the mother). The instructor individually suggests a particular position for the child: on the mother's back, on the neck, in the arms, etc., but visually controls and reduces the load if necessary. This part is aimed at increasing the aerobic work of the body of women, increasing energy consumption, burning fat, training the cardiovascular and respiratory systems, improving performance. Then we offer women strength exercises: for the muscles of the back, press, arms, buttocks. If the child is small, the mother can use it as a weighting agent. For example, the woman lying on her back, legs bent apart, the child in front of her in the outstretched arms: bending and stretching arms (lowering the child, you need to kiss him in the belly). If the child is already large (more than 12 kilograms), and it is very difficult for the mother to lift, dumbbells, stuffed balls, discs for mini barbells instead of the load are used. The children are nearby and try to repeat the movements of their mothers, but they have a toy in their hands.

In the second half of the main part, the instructor gives out tasks for the children, which they perform together with their mothers, since any child trusts one's mother most of all. In this part of the training, there is learning, repetition and improvement of motor actions, and the development of physical abilities in children. The following equipment is used here: balls (rubber, plastic, light beach balls), sticks, small hoops, step platforms, rubber hemispheres (bossu), children's tunnels, rollers for pilates classes, fluted children's mats (for the prevention of flat feet), a mini trampoline, a children's mini basketball stand, fitballs and other equipment. Next, outdoor games are held to strengthen the skill of performing the learned motor actions.

The final part (5-10 minutes) In this part of the training, a set of exercises on large balls (fitballs) is performed under the relaxation music. Exercises for stretching, relaxation and posture are used. Mothers soothe children with the help of massage, relieve tension of the child's muscles which were working during the class. At the end of the lesson, there is the obligatory ritual of "farewell". The instructor gathers everyone in a circle, says how well done everyone is, that he or she will look forward to the next meeting, then gives each child one's palm with the words "high five, you're good!" and the child should clap the instructor's palm in response. 


\section{The results of the study and their discussion}

The conducted survey-testing among 143 women showed that $7 \%$ of the respondents had a high level of competence in physical education and the development of their babies; the average level of competence was shown by $26 \%$; the level below the average showed $31 \%$ of the respondents; the low level of competence was found in 36\% of women (Fig. 4).

Figure 4 - Results of the parent competence test

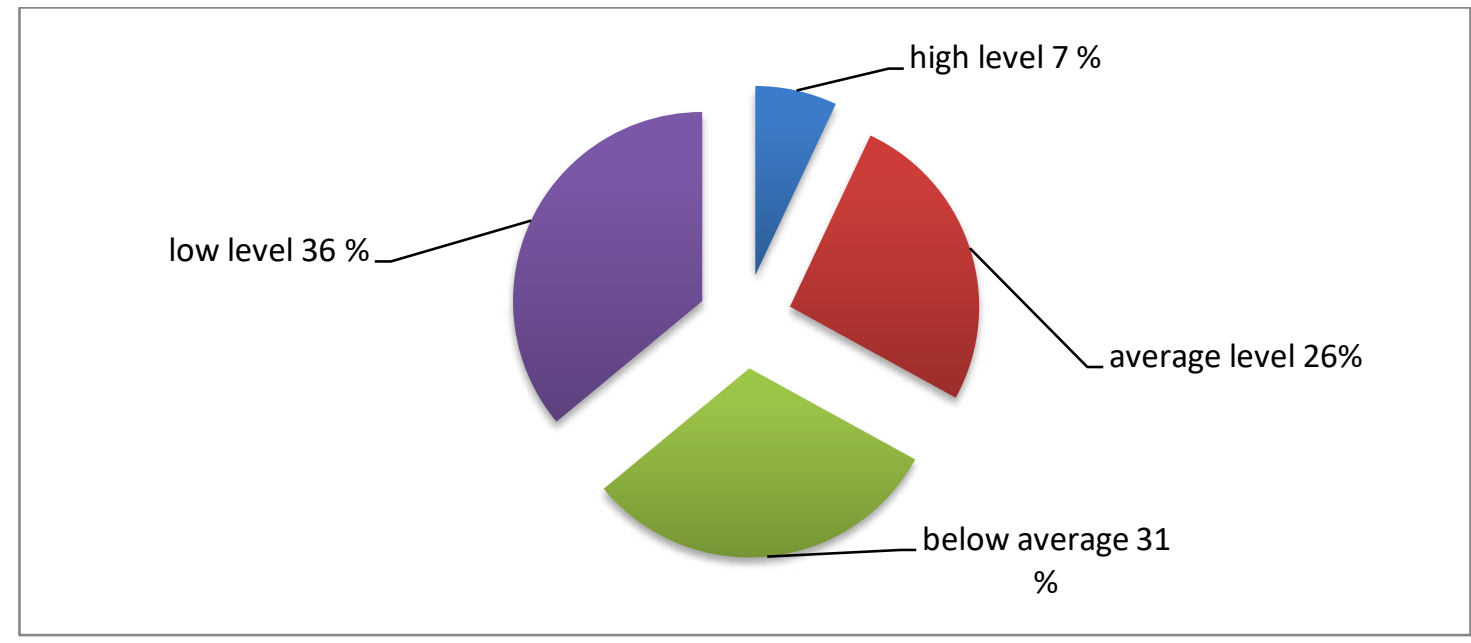

Source: Collection of the authors

The results of the programm impact on women. As part of the study, the positive dynamics of the development of women physical fitness performance during the pedagogical experiment was revealed.

The analysis of the final results of testing on the physical fitness of women in the two groups showed that both in the control group and in the experimental group there were significant improvements in all the studied indicators $(\mathrm{P}<0.01)$. It should be noted that the subjects of the control group were engaged without children, and 60 minutes of classes were aimed at improving their psychophysical state. In the experimental group, only 40-45 minutes were allocated for this, of which about 10-15 minutes the women were distracted by their children (taking them to the toilet, giving them water, wiping their noses, etc.). Therefore, the final results of physical fitness of women in the control group were higher than in the experimental group, except for the balance test - "Standing on one leg with eyes closed" (Fig.5). 
Figure 5 - Dynamics of the results of physical fitness of the two groups during the experiment

\section{- Control group - Experimental group}

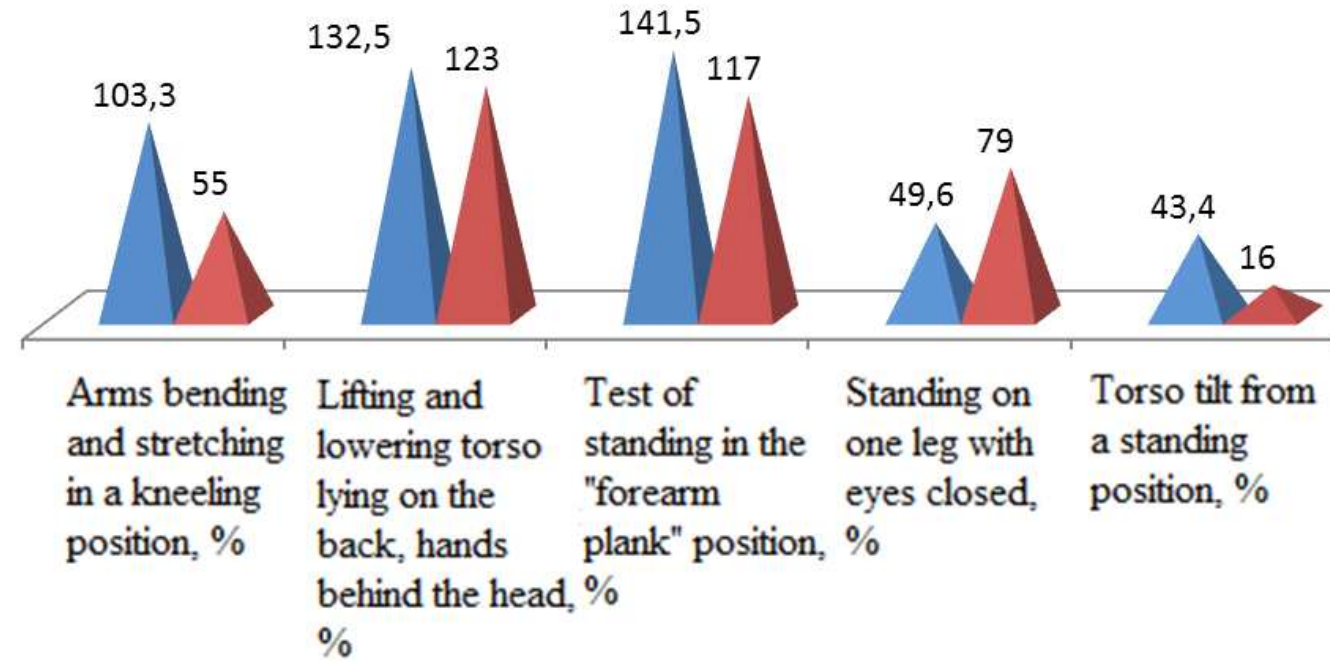

Source: Collection of the authors

After analyzing the dynamics of the results in the experimental group, we found the following significant changes:

- arms bending and stretching in a kneeling position - knee push-ups (test on strength of arms and shoulder girdle) indicator had a $55 \%$ increase $(\mathrm{P}<0.01)$;

- lifting and lowering back down the torso lying on the back, hands behind the head (power endurance) indicator had a $123 \%$ increase $(\mathrm{P}<0,01)$;

- test of standing in the "forearm plank" position (static strength endurance of the muscles of the arms, shoulder girdle, body's natural corset) indicator showed a $117 \%$ increase $(\mathrm{P}<0,01)$;

- test "standing on one leg with eyes closed" (coordination ability, ability to maintain balance) results of women in the experimental group showed $79 \%$ improvement $(\mathrm{P}<0.01)$;

- flexibility test of torso tilt from a standing position (active flexibility of the spine) the indicators of women in the control group improved by $16 \%(\mathrm{P}<0.01)$.

The data obtained indicate that, despite the lower efficiency of the results enhancement of women in the experimental group compared to the control group, the method developed by us had a positive effect on the indicators of physical fitness of women. During the final survey, the participants of the experimental group noted improvements in their psychophysical state. During the experiment, the competence of women in the control group increased by $17 \%$ 
Sergey Alekseevich YARUSHIN; Valentin Dmitrievich IVANOV; Tatyana Nikolaevna VLASENKO; Viktor Ivanovich GONCHAROV; Tatyana Anatolevna BANKU; Evgeniya Aleksandrovna GERASIMCHUK; Olga Sergeevna KRUTSKIH and Tatyana Valerievna PINCHUK

$(\mathrm{P}<0.05)$, the average indicator corresponded to the average level; in the experimental group by $53 \%(\mathrm{P}<0.01)$, the average indicator in the group corresponded to a high level of competence.

\section{The results of the impact of the methodology on children}

In the children of the experimental group, during the lessons, the greatest increase was revealed in the indicator of skills of throwing and catching the ball. The result improved from 0.1 points to 3.3 points $(3200 \%)(\mathrm{P}<0.01)$. The second biggest improvement was in the crawling through the tunnel skills. The average score for the group increased from 0.2 points to 4.5 points $(2150 \%)(\mathrm{P}<0.01)$. By the end of the experiment, the kids were already crawling through a two-meter children's tunnel on their own, while some were holding a toy in their hand, while others were pushing the ball in front of them. No less significant results were obtained for other tested skills. In the control group, improvements occurred in all indicators, except for the skills of crawling through the tunnel $(\mathrm{P}>0.05)$. The highest increase was found in the indicator of running skills, the results increased by an average of $1200 \%(\mathrm{P}<0.01)$ (Table $1)$.

Table 1 - Changes in the indicators of motor skills in children during the experiment $(n=10)$

\begin{tabular}{|c|c|c|c|c|}
\hline Stages & $\begin{array}{c}\text { Before the } \\
\text { experiment }\end{array}$ & $\begin{array}{c}\text { After the } \\
\text { experiment }\end{array}$ & \multicolumn{2}{c|}{ Differences } \\
\hline Experimental group & & \\
\hline Tested skills & $\overline{\mathrm{M}} \pm \mathrm{m}$ & $\overline{\mathrm{M}} \pm \mathrm{m}$ & $\%$ & $\mathrm{P}$ \\
\hline Walking skills, score & $1,1 \pm 0,11$ & $4,8 \pm 0,11$ & 336 & $\mathrm{P}<0,01$ \\
\hline Running skills, score & $0,1 \pm 0,11$ & $2,1 \pm 0,11$ & 2000 & $\mathrm{P}<0,01$ \\
\hline Balance skills, score & $0,5 \pm 0,11$ & $4,6 \pm 0,11$ & 820 & $\mathrm{P}<0,01$ \\
\hline Throwing skills, score & $0,2 \pm 0,11$ & $3,7 \pm 0,32$ & 1750 & $\mathrm{P}<0,01$ \\
\hline Skills of throwing and catching the ball, & $0,1 \pm 0,11$ & $3,3 \pm 0,11$ & 3200 & $\mathrm{P}<0,01$ \\
\hline score & $0,20 \pm 0,11$ & $4,50 \pm 0,11$ & 2150 & $\mathrm{P}<0,01$ \\
\hline Tunnel crawling skills, score & $\mathrm{Control}$ group & & & \\
\hline Tested skills & $\overline{\mathrm{M}} \pm \mathrm{m}$ & $\overline{\mathrm{M}} \pm \mathrm{m}$ & $\%$ & $\mathrm{P}$ \\
\hline Walking skills, score & $1,20 \pm 0,11$ & $2,50 \pm 0,22$ & 108 & $\mathrm{P}<0,01$ \\
\hline Running skills, score & $0,10 \pm 0,11$ & $1,30 \pm 0,11$ & 1200 & $\mathrm{P}<0,01$ \\
\hline Balance skills, score & $0,50 \pm 0,11$ & $1,20 \pm 0,22$ & 140 & $\mathrm{P}<0,05$ \\
\hline Throwing skills, score & $0,10 \pm 0,11$ & $0,60 \pm 0,11$ & 500 & $\mathrm{P}<0,01$ \\
\hline Skills of throwing and catching the ball, & $0,10 \pm 0,11$ & $0,50 \pm 0,11$ & 400 & $\mathrm{P}<0,05$ \\
\hline score & $0,40 \pm 0,11$ & $0,80 \pm 0,22$ & 100 & $\mathrm{P}>0,05$ \\
\hline Tunnel crawling skills, score & & & \\
\hline
\end{tabular}

Source: Prepared by the authors

A comparison of the final test results of the children of the two groups revealed a significant lag in the development of basic motor skills in the control group children $(\mathrm{P}<0.01)$ 
(Table 2). The biggest lag we found was in the development of tunnel crawling skills and balance skills.

Table 2 - The results of comparison the indicators of motor skills in children of the two groups at the end of the experiment

\begin{tabular}{|c|c|c|c|c|}
\hline Groups & CG (n=10) & EG (n=10) & \multicolumn{2}{|c|}{ Differences } \\
\hline Tested skills & $\overline{\mathrm{M}} \pm \mathrm{m}$ & $\overline{\mathrm{M}} \pm \mathrm{m}$ & $\mathrm{t}$ & $\mathrm{P}$ \\
\hline Walking skills, score & $2,50 \pm 0,22$ & $4,80 \pm 0,11$ & 9.50 & $\mathrm{P}<0,01$ \\
\hline Running skills, score & $1,30 \pm 0,11$ & $2,10 \pm 0,11$ & 5.23 & $\mathrm{P}<0,01$ \\
\hline Balance skills, score & $1,20 \pm 0,22$ & $4,60 \pm 0,11$ & 14,05 & $\mathrm{P}<0,01$ \\
\hline Throwing skills, score & $0,60 \pm 0,11$ & $3,70 \pm 0,32$ & 9,06 & $\mathrm{P}<0,01$ \\
\hline $\begin{array}{c}\text { Skills of throwing and catching the } \\
\text { ball, score }\end{array}$ & $0,50 \pm 0,11$ & $3,30 \pm 0,11$ & 18,29 & $\mathrm{P}<0,01$ \\
\hline Tunnel crawling skills, score & $0,80 \pm 0,22$ & $4,50 \pm 0,11$ & 15,3 & $\mathrm{P}<0,01$ \\
\hline
\end{tabular}

Source: Prepared by the authors

The data obtained indicate that children learn motor skills much faster in a group, and the mother's guiding and insuring actions give them confidence in their abilities.

We had the opportunity to visually compare the results of women taken part in our experiment, with children of 3 and 4 years old, already going to kindergarten. Kids who studied according to the presented developed methodology are more mobile, able of choosing the right direction of movement, they performed tasks well, invented complex motor actions themselves, trying to copy the actions of their mother or other children. All the children of the experimental group were developed ahead of their peers in motor skills and were ready to study in a preschool educational institution in terms of physical development. We found confirmation of A. A.Tsetiev's statement "Through the physical education classes you can see how the child becomes an individual" (TSETIEV; ISAKOVA; KALASHNIKOVA, 2018). Through the use of competitive elements in the tasks, we could see each child aspiring to stand out, and if it was not possible for a child to run first, it tried to succeed in another task. By the end of the experiment, all the children knew the rules of behavior: they shared toys, greeted everyone at the beginning of the training and said goodbye at the end. They helped to prepare the hall for the lesson and clean up after it.

\section{Conclusion}

The development of basic vital motor skills occurs during early childhood from 1 year to 3 years. It is during this period that the physical education of the child is under the parents' control (Federal Law of 29.12.2012 No273-FZ) (RUSSIA, 2012). 
Studies have shown that not all women are competent in this regard: only $7 \%$ of the women surveyed had a high level of competence and $26 \%$ had an average level of competence. While the low level of development of parents' competence in the field of physical education and the development of their children corresponded to $36 \%$ of women.

Statistical analysis of the results of the study shows that the developed method of joint sports and recreation classes program "Mother+Baby" significantly improved the indicators of women's physical fitness, their psychological state and competence in physical education and early childhood development. The effectiveness of the elaborated programm on the development of motor skills in young children is proved.

\section{REFERENCES}

BUZYKOVA, S. "Pedagogy of early childhood" by I. A. Sikorsky: theoretical and methodological aspect. Scientific notes of Pacific State University, v. 8, n 1-1, p. 168-172, 2017.

FEDOROVA, S. Psychomotor gifting as a phenomenon of physical development of preschoolers. Personal education, n 1, p. 72-81, 2014.

GOLUBEVA, T. N. Socialization of young children in the conditions of a group of short-term stay of children during admission to the preschool educational institution. Education in the Kirov Region, v. 4, n. 32, p. 37-39, 2014.

GORCHAKOVA, T. A.; TSIVILEVA, S. Psychological and pedagogical support for families raising young children through the organization of the advisory and methodological club "Help your child". Early assistance to children and their families: trajectory of professional growth. In: INTERNATIONAL SCIENTIFIC AND PRACTICAL CONFERENCE, 2., 2019, Saint-Petersburg. Proceedings [...]. Saint-Petersburg, 2019. p. 35-38.

GULYAN, A. E. Influence of family physical education on physical development of preschool children. Problems of Pedagogy, v. 7, n. 30, p. 34-37, 2017.

ISLAMOVA, A. T. Features of adaptation of young children to preschool. Problems and trends of scientific research in the education system. In: INTERNATIONAL SCIENTIFIC AND PRACTICAL CONFERENCE, 2019, Ufa. Proceedings [...]. Ufa, 2019, p. 77-79.

KRAVCHUK, A. I. Complex physical training of children of early and preschool age (state and prospects). Physical Education: Education, Education, Training, n. 4, p. 26-31, 2007.

KROKHINA, T. A.; APARIEVA, T. G. Features of swimming classes in the groups "mother and baby" (using the example of children 3 years old). Physical Education and Sports Training, v. 1, n. 11, p. 12-16, 2015.

LARECHINA, E. V. Development of emotional relations between mother and child: a methodological manual. St. Petersburg, 2004. 160 p. 
MARTYNOV, A. A. Physical development of young children by means of dynamic gymnastics. Physical Education and Sports Training, v. 4, n. 22, p. 18-23, 2017.

OBNOSOV, V. N.; ASOMBA, N. S. Communication and development of a child's speech during infancy, early and preschool childhood. Science and Education, v. 3, n. 1, p. 98, 2020

RUSSIA. Federal Law of 29.12.2012 No273-FZ. On Education in the Russian Federation" (Electronic Resource). 2012. Available at: https://fzrf.su/zakon/ob-obrazovanii-273-fz/. Access: 10 Mar. 2021.

SMALL, I. I. Physical capabilities and development of young children (2-3 years old). Methodist, n. 5, p. 60-62, 2015.

SMIRNOVA, E. O.; GALIGUZOVA, L. N.; MESHCHERYAKOVA, S. Methodological materials for the comprehensive educational program for young children. "First Steps"; Part 2. Moscow, 2018. 160 p.

TEREKHINA, R. N.; MEDVEDEV, E. N.; SUPRUN, A. A. Program of early physical development of children (from birth to 10 years): textbook. Moscow, 2019. p. 5.

TSETIEV, A. A.; ISAKOVA, M. A.; KALASHNIKOVA, L. D. The main tasks of the physical education process in the formation of motor skills and skills of children of early preschool age. Scientific Notes of the University named after P.F. Lesgaft, v. 6, n. 160, p. 275-278, 2018.

VLASENKO, T. N.; POPESCU, S. Features of organizing recreational joint classes of women with young children. In the collection: Physical culture and sports in modern society. In: ALL-RUSSIAN SCIENTIFIC AND PRACTICAL CONFERENCE, Khabarovsk, 2019. Proceedings [...]. Khabarovsk, 2019. p. 71-75. 


\section{How to reference this paper}

YARUSHIN, S. A.; IVANOV, V. D.; VLASENKO, T. N.; GONCHAROV, V. I.; BANKU, T. A.; GERASIMCHUK, E. A.; KRUTSKIH, O. S.; PINCHUK, T. V. Methodology of joint physical education and recreation classes under the program "mom + baby". Revista online de Política e Gestão Educacional, Araraquara, v. 25, n. 3, p. 2519-2534, Sep./Dec. 2021. e-ISSN: 1519-9029. DOI: https://doi.org/10.22633/rpge.v25i2.16091

Submitted: 19/09/2021

Required revisions: 17/10/2021

Approved: 22/11/2021

Published: 08/12/2021 